Cordova Jurnal

ISSN (P) 2302-3155,

(e) 2714-5808

Vol. 9, No. 12019

\title{
THE USAGE OF YOUTUBE VIDEO IN TEACHING ENGLISH FOR YOUNG LEARNER (TEYL) FOR SIXTH SEMESTER STUDENTS OF ENGLISH DEPARTMENT
}

\author{
Nurnaningsih, Arin Arianti
}

\author{
English Department, Undergraduate Program, Faculty of Teacher \\ Training and Education \\ Universitas Veteran Bangun Nusantara Sukoharjo, Indonesia \\ (E-mail: nurnaninx@yahoo.co.id, ariantiarin7@gmail.com)
}

\begin{abstract}
The objective of the research is to know the student's mastery in using YouTube as teaching media while the students learn to be a peer teacher in TEYL. TEYL is Teaching English for Young Learner is one of the subjects that is taught for sixth semester students of English Department in Veteran Bangun Nusantara University of Sukoharjo. Students learnt to teach their friends as if their friends were young learner students by using many kinds of teaching Medias. Youtube video is the most favorite teaching media because it is easy to get by downloading it or just see it. Qualitative method was used in the study. The subject of the study was $6^{\text {th }}$ semester students of English Department. The collecting data of the study were used observation, interview, and documentation. The observation was used in order to know students' teaching mastery about YouTube as a teaching media. The interview used to know the students feel, inspiration of using YouTube, and the application of YouTube in class. The documentation itself were divided into three. First was video recording, second was note taking and third was pictures. While the data of the research was the script based on the video recording. Based on the research, the students used YouTube as teaching media with different treatment. 1. Collecting some videos in a PowerPoint the way to serve it to the other students, 2. YouTube video was combined with some written explanation in a PowerPoint, 3. the other students only used a video then played it as a teaching medium, 4. Students downloaded songs video from YouTube but it does not play in class but the students use the song by changing the lyric. Then the students sang it with the variation lyric they already made.
\end{abstract}

Keywords: Teaching Media, Youtube Video, Young Learner 
Cordova Jurnal

ISSN (P) 2302-3155,

(e) 2714-5808

Vol. 9, No. 12019
Jurnal kajian Bahasa dan Budaya terbit 2 kali setahun oleh UPT. Pusat Pengembangan

Bahasa (P2B) UIN Mataram. Tersedia online pada

https://journal.uinmataram.ac.id/index.php/cordova

\section{INTRODUCTION}

TEYL stands for Teaching English for young Learner is one of the subjects studied by students in the sixth semester of the English Education study program. This course is given before students have the opportunity to practice teaching in schools in junior high schools or senior high schools or vocational high schools. Graduates from the English Department of Veterans Bangun Nusantara University of Sukoharjo or Univet Bantara Sukoharjo. In TEYL courses, students are prepared to be better prepared for the immaterial side where students learn to teach classmates. The immaterial preparation referred to here is mental preparation and teaching media. Mental preparation is obtained by students in this course because they learn teaching practices in front of classmates. The TEYL learning conditions in the classroom are very crowded because students pretend to be young learners. Even though the class in TEYL course is busy, it can be seen from the expressions of students who pretend to be students that they enjoy this TEYL class. Students can act as small students who are being taught by a teacher who in this case is one of the classmates and students are free to express themselves in class. Students are free to ask questions about what is being explained by their friends, as if they do not know and understand them even it is not uncommon for students to laugh at friends who are learning to teach in class which makes students feel happy to be in the TEYL class. It has been found in several students who rarely come to college in one semester but are always present during TEYL's class schedule. This is a challenge for students who practice teaching or 
Cordova Jurnal

ISSN (P) 2302-3155,

(e) 2714-5808

Vol. 9, No. 12019
Jurnal kajian Bahasa dan Budaya terbit 2 kali setahun oleh UPT. Pusat Pengembangan

Bahasa (P2B) UIN Mataram. Tersedia online pada

https://journal.uinmataram.ac.id/index.php/cordova

become teachers in front of the class to be able to make friends or classmates calm down. When one student practices teaching in front of the class alone like this, this is what is referred to as peer teaching, while students who teach in front of the class are called peer teachers. The second preparation is preparation for teaching media. The second preparation is mandatory because when teaching in TEYL courses, students are required to teach by bringing teaching media in front of the classroom based on the field conditions of young learner students and the material taught to students. The Young learner student material taught by students is adjusted to the curriculum adopted, Revised edition 2013 Curriculum. The condition of students in the field is related to the state of the class, the condition of students who are busy with understanding of the material or crowded because it is difficult to manage or students who are quiet of material understanding or not. This is the consideration of students who teach in TEYL classes must be able to decide even make teaching media that is suitable for young learner students. Teaching media that is interesting will be a tool for teachers to be able to make the classroom calm and teaching media also makes it easier for students to understand the material.

Based on an explanation of the learning process in the TEYL class, students who teach peers in one class or in a group are called Peer Teaching. The definition of Peer Teaching itself is the use of teaching and learning strategies in which students learn with and from each other without the immediate intervention of a teacher (Boud et al., 1999: 413). Based on the explanation from Boud and his friends, the learning 
Cordova Jurnal

ISSN (P) 2302-3155,

(e) 2714-5808

Vol. 9, No. 12019
Jurnal kajian Bahasa dan Budaya terbit 2 kali setahun oleh UPT. Pusat Pengembangan

Bahasa (P2B) UIN Mataram. Tersedia online pada

https://journal.uinmataram.ac.id/index.php/cordova

process by asking one student to teach other friends is teaching Peer teaching with the teacher's position outside the learning circle because the class is in the hands of students who are in front of the class to teach. When in front of the class the student is responsible for the order and continuity of the learning process. While the instructor's position is just to see and observe the student who is teaching and can provide feedback or feedback to the student when the course ends. This feedback is needed so students know how to perform during teaching in the classroom, how well they teach or what needs to be done to produce a creative and interesting learning process. In accordance with the explanation from Baud, the learning process of students from the beginning of learning, opening the learning process, until the end of the learning process, giving an evaluation and at the same time assessing the right or wrong of the questions that have been done. In this TEYL course, students are free to develop material taught in class by considering appropriate learning media that are interesting for students or in this case friends in one class. RPP or Learning Implementation Plan is not prioritized in this the subject because in the Microteaching students have gotten a way to make RPP based on an existing syllabus that is adapted to the curriculum being implemented in Indonesia.

TEYL courses are more focused on developing material and combining material with creative and interesting media for students. To find out the learning media and learning materials, it is necessary to return to the information at the beginning that knowledge of student characteristics is needed here. The reason is that elementary students 
Cordova Jurnal

ISSN (P) 2302-3155,

(e) 2714-5808

Vol. 9, No. 12019
Jurnal kajian Bahasa dan Budaya terbit 2 kali setahun oleh UPT. Pusat Pengembangan

Bahasa (P2B) UIN Mataram. Tersedia online pada

https://journal.uinmataram.ac.id/index.php/cordova

and teenage students have somewhat different interests. Elementary students tend to be more active in gross motor skills in learning and playing while teenage students are more likely to be active in fine motor skills.

Teaching media used in TEYL are adapted to the characteristics of young learner students living in the industrial 4.0 era. In this era young learner students are already close and accustomed to knowing and using the internet. Many young learners who love YouTube and even YouTube are the first sites they visit. The reason is that at an early age, even when young learners cannot operate the gadget, but they can enjoy YouTube because YouTube contains interesting videos such as movies, songs, fragments of news, and even tutorials about doing or making things. YouTube has both positive and negative sides depending on how users or connoisseurs of YouTube use it. For a teacher who lives in the Industrial 4.0 era, it must be able to adjust to the changing times. Teachers at this time must be able to use technology that is growing rapidly in the industrial 4.0 era, one of which is Youtube. This is a challenge for teachers at this time to use Youtube as a teaching medium to teach as a tool to test or as a student evaluation tool.

Some researchers have explored about the problems in the using teaching media, especially connects it to the internet. Hence it is necessary to know how the teacher uses the internet as teaching media in teaching learning process of English. Therefore, it is also necessary to make the peer teachers in TEYL of English department more creative in teaching English by using internet. It gives a benefit for peer teachers to 
Cordova Jurnal

ISSN (P) 2302-3155,

(e) 2714-5808

Vol. 9, No. 12019
Jurnal kajian Bahasa dan Budaya terbit 2 kali setahun oleh UPT. Pusat Pengembangan

Bahasa (P2B) UIN Mataram. Tersedia online pada

https://journal.uinmataram.ac.id/index.php/cordova

be able to attract their students to pay attention on the material. Besides, various teaching media give the understanding for the student that English is fun and it gives the easiest way to learn and understand English. Above of all, peer teachers can be more creative in teaching while peer teachers' practice to teach in the seventh semester. Seventh semester is a semester, whereas peer teachers' practice to be a teacher in junior and senior high school in Sukoharjo areas.

Hereby the research conducted a research entitled the usage of YouTube video in Teaching English For Young Learner (TEYL) for sixth semester students of the English department. to make a conclusion based on the research, there is a question tried to be answered, as follows: How is the students' mastery in using YouTube as teaching media in TEYL?

\section{LITERATURE REVIEW}

In recent years, the use of video in English classes has grown rapidly as a result of the increasing emphasis on communicative techniques. Being a rich and valuable resource, video is well-liked by both students and teacher (Hemei, 1997:45). Students like it because video presentations are interesting, challenging, and stimulating to watch.

Another important factor for teacher that makes it more interesting and enjoyable is that it helps to promote comprehension. Video makes meaning clearer by illustrating relationships in a way that is not possible with words, which proves a well-known saying that a picture is worth thousand words. Two minutes of video can provide an hour of classroom work, or it can be used to introduce a range of activity 
Cordova Jurnal

ISSN (P) 2302-3155,

(e) 2714-5808

Vol. 9, No. 12019
Jurnal kajian Bahasa dan Budaya terbit 2 kali setahun oleh UPT. Pusat Pengembangan

Bahasa (P2B) UIN Mataram. Tersedia online pada

https://journal.uinmataram.ac.id/index.php/cordova

for five minutes. A ten-minute programmed can be useful for more advanced students. Less advanced students may wish something much shorter because their limited command of the language also limits their attention span.

Definition of video was linked to text and graphics and the way of playing of video jumping is from one point to another was quite slow, and the norm was to watch a videotape from beginning to end (Brophhy, 2004). Actually enjoying video is the same as we are watching text and graphic that made in a good combination, so audience can see the beautiful scene on the television. The way we are watching video can see it toward to the end of the story or we can jump to the story that we like to watch.

The usage of video in teaching learning process can have advantage like Olivero said in Brophy (2004) said that Advantage of video is the ability to substitute live observations with videotaped supervision.

Besides there are some role for teacher in video application in a class, it is like Clyde and Delohery, 2005: 34-36) the teacher is as a controller for what happened in the class, for example teacher can control what the students do but what they speak as well while they are also watching the video film. Then teacher is as a good organizer in teaching the foreign language through video. It means that not give useless information or confusing instructions to the students in order not to waste a lot of time. Teacher should clearly explain what the students are going to watch and what their task is. The next is the teacher is being 
Cordova Jurnal

ISSN (P) 2302-3155,

(e) 2714-5808

Vol. 9, No. 12019
Jurnal kajian Bahasa dan Budaya terbit 2 kali setahun oleh UPT. Pusat Pengembangan

Bahasa (P2B) UIN Mataram. Tersedia online pada

https://journal.uinmataram.ac.id/index.php/cordova

a prompter. When there is a silence viewing or what the students are confused about what to do next, she is expected to encourage students' participation. . When there is a silence viewing or what the students are confused about what to do next, she is expected to encourage students' participation.

\section{METHOD}

The research focussed on a nature problem that it could not be made. The reason is the research analyzed human. Human is dynamic. It relates to suggestions said about qualitative research (2011: 15). The conclusion that can be drawn from Sugiyono's explanation is that this research was a qualitative study because it examined the real conditions that existed in the classroom learning of English subjects focusing on the ability to write in English.

\section{PARTICIPANT}

The participants were the sixth semester students of Univet Bantara Sukoharjo in the academic year of 2018/2019. The participant was A class because it was an active class. It was the interaction between student acted as peer teacher and students acted as students. It was a peer teaching class. 
Cordova Jurnal

ISSN (P) 2302-3155,

(e) 2714-5808

Vol. 9, No. 12019
Jurnal kajian Bahasa dan Budaya terbit 2 kali setahun oleh UPT. Pusat Pengembangan

Bahasa (P2B) UIN Mataram. Tersedia online pada

https://journal.uinmataram.ac.id/index.php/cordova

\section{PROCEDURE}

The research procedure had some steps that were done in the research.
a. archival the recording

The researchers observed and recorded the peer teaching class in TEYL

b. documentation

The researchers took documentation of peer teacher evaluation

c. Interview

The researcher made an interview with two students. The first interviewee represented the clever one. The second student wasn't the clever one. Then it should be written in the transcript. Finally the researcher should make coding of the interview and it should be matched to peer teaching steps.

d. ComparingThe next step was comparable between the coding and video recording. Both had to match to second chapter or the underlying theory. The result was written in discussion.

\section{DATA COLLECTION}

Yin (2009: 102) suggests that if documentation, archival recordings, interviews, direct observation, participant observation, and physical artifact as sources of evidence. This research used three of these sources: interviews, archival recording, and documentation.

In collecting the data, researchers used interview, archival recording and documentation to get data of students' reaction in the TEYL's class while they were taught through Peer Taching. 
Cordova Jurnal

ISSN (P) 2302-3155,

(e) 2714-5808

Vol. 9, No. 12019
Jurnal kajian Bahasa dan Budaya terbit 2 kali setahun oleh UPT. Pusat Pengembangan

Bahasa (P2B) UIN Mataram. Tersedia online pada

https://journal.uinmataram.ac.id/index.php/cordova

\section{DATA ANALYSIS}

This research used interactive analytical technique. Miles and Hubberman, (1994: 26) stated that "activity in the qualitative data is analyzed interactively and continues over until completed, so the data are already saturated". Activities in the analyzing data where data reduction, data display, and conclusion: drawing/verification. The activities could be seen below,

The figure 1 Technique of Analyzing Data by Miles and Hubberman (1994:12)

Components of Data Analysis: Interactive Mrodel

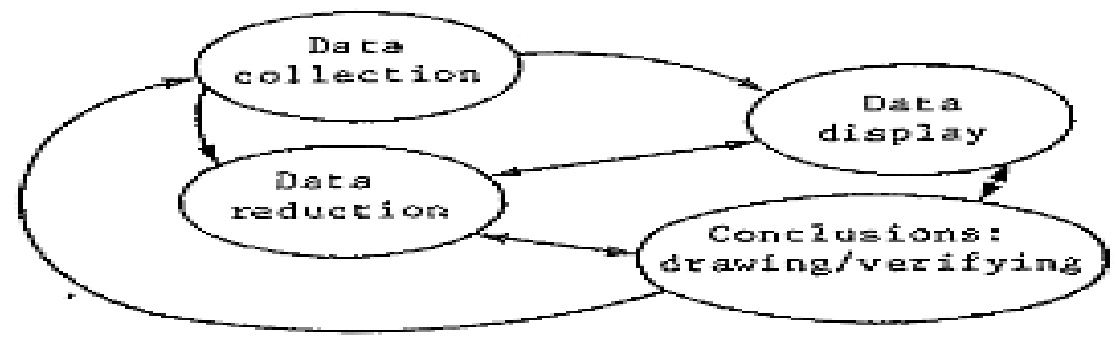

\section{FINDINGS AND DISCUSSION}

\section{FINDINGS}

Teaching learning process in TEYL is not the same as others subjects. Students tried to be a teacher in class or it usually called as peer teacher because every student tried to teach his or her friends. Based on the students' experience of being a peer tacher in the TEYL class, there is something worth noting, namely the use of teaching media used in the TEYL class. The most commonly used learning media was videos 
Cordova Jurnal

ISSN (P) 2302-3155,

(e) 2714-5808

Vol. 9, No. 12019
Jurnal kajian Bahasa dan Budaya terbit 2 kali setahun oleh UPT. Pusat Pengembangan

Bahasa (P2B) UIN Mataram. Tersedia online pada

https://journal.uinmataram.ac.id/index.php/cordova

downloaded from Youtube. Next interesting is "The student's mastery used YouTube as teaching media in TEYL"

Peer teacher in teaching used learning media that had the aim to make the task of peer teachers explained easier and students found it was easier to understand the material with the learning media. Teachers in this case were peer teachers very helped by the existence of learning media. This learning media could be used by peer teachers as a tool to open lessons or tools to start explaining the material. So that the peer teacher was easier to explain the material to students. In addition, learning media caould be used at the end after the lighting of the teacher. The aim was to make learning more easily understood by students because it was explained twice. The first was an explanation from the teacher, the second was an explanation in the form of visualization on videos downloaded from YouTube. YouTube helped in the visualization of an event or phenomenon of material explained by a peer teacher. In addition, YouTube could be used for evaluations to students in order to measure the level of students' ability to understand the material, if Youtube was played at the end of learning after an explanation from the teacher or after students had a discussion.

You tube is as the most famaous tube in the world. It can be used to be a teaching media in class. It already used by the A class. Class A, amounting to 35 students, almost half of them use YouTube as a teaching medium. Classmates of peer teacher were as students, and they enjoyed the Youtube played. It could be seen from the students' response for the Youtube played. There were not any activities but watched the played. 
Cordova Jurnal

ISSN (P) 2302-3155,

(e) 2714-5808

Vol. 9, No. 12019
Jurnal kajian Bahasa dan Budaya terbit 2 kali setahun oleh UPT. Pusat Pengembangan

Bahasa (P2B) UIN Mataram. Tersedia online pada

https://journal.uinmataram.ac.id/index.php/cordova

Based on observations in the classroom, peer teachers downloaded YouTube in several types of forms according to the needs of teaching material.
a. Video of songs
b. Video of conversation
c. Short video of a movie or thriller

\section{DISCUSSION}

Based on what has been discussed in Findings, the explanation for the student's mastery used by using YouTube as teaching media in TEYL is as follows.

In TEYL learning there was always noise or the class becomes crowded because students were laugh at the way the peer teacher in this case was the student's friend when teaching in front of the class. This also took place in class A. The learning media used in the class can help peer teachers to control students in this case were peer teacher classmates so that students in the class were not busy alone or rowdy in the classroom during the learning process. The many learning media used in the classroom, the use of this video was the most widely used and each time the video was played the students in the class would be silent to pay attention to the video playing in class. The video used in class was a video obtained from YouTube that had been downloaded. So, it could be concluded that the video used is not a video made by yourself or purchased from somewhere. 
Cordova Jurnal

ISSN (P) 2302-3155,

(e) 2714-5808

Vol. 9, No. 12019
Jurnal kajian Bahasa dan Budaya terbit 2 kali setahun oleh UPT. Pusat Pengembangan

Bahasa (P2B) UIN Mataram. Tersedia online pada

https://journal.uinmataram.ac.id/index.php/cordova

Based on the experienced peer teaching taught in class, there were two types of peer teachers in using Youtube, namely:

a. Applied immediately

Peer teachers who used this type, they usually downloaded videos from YouTube. Then the peer teachers did not change the contents of the video that had been downloaded in the presentation in the classroom, they immediately used it to teach

b. As inspiration

Peer teacher changed or modified videos that had been downloaded from YouTube. These changes were based on the needs of the material they teach. What they did, peer teachers used youtube video as a slide show on PowerPoint. This could be done in two ways, namely: first, the peer teacher displayed the downloaded video and then cut each part by using paint, then arranged in a PowerPoint. Second, Peer teacher edited Youtube using Paint found on their laptop devices. Youtube was cut in the form of one catch or as needed. Furthermore, the catch was combined with an explanation of the material according to the catch that had been made.

In addition to applying video with PowerPoint, there were other things that peer teachers did with Youtube videos. Videos that had been downloaded were not shown in class but only as inspiration in making songs that they use to teach in class. The thing that the peer teacher did was replacing the song lyrics but with the same rhythm or tone as the songs contained in the video. An example is the ABC Alphabet song changed to count one, two three but with the same tone as the tone 
Cordova Jurnal

ISSN (P) 2302-3155,

(e) 2714-5808

Vol. 9, No. 12019
Jurnal kajian Bahasa dan Budaya terbit 2 kali setahun oleh UPT. Pusat Pengembangan

Bahasa (P2B) UIN Mataram. Tersedia online pada

https://journal.uinmataram.ac.id/index.php/cordova

contained in the ABC Alphabet song. Peer teacher or teacher in teaching young learner students was better advised to use songs that are familiar with students with the aim that students were easier to memorize the lyrics of the song. This learning model was usually used to teach vocabulary.

In addition to being seen from the difference in how to use Youtube videos in class, there were other interesting things to be observed, namely, there were several types of youtube downloaded.

a. Video of songs

This video of songs was used to teach young learner students in the kidergardern class. Students were asked to listen, paid attention and then peer teacher and students sang the song playing in the video.

This video could be displayed intact or even not displayed at all Karen apeer teacher changes the lyrics of the song. This was doing because peer teachers needed strong inspiration in making song lyrics. Downloaded songs were songs that are familiar with young learners, such as $A B C$ Alphabet. This type of video was most often used in class because it was easy and fun. Video songs that were downloaded there were those that use lyrics, there were also songs that did not use lyrics. The song videos that used the lyrics were downloaded usually to be displayed in full in class.

\section{b. Video of conversation}

This conversation video, usually used to teach elementary students, especially starting from class 3 . In this class, students already had an adequate amount of vocabulary to make short conversations and 
Cordova Jurnal

ISSN (P) 2302-3155,

(e) 2714-5808

Vol. 9, No. 12019
Jurnal kajian Bahasa dan Budaya terbit 2 kali setahun oleh UPT. Pusat Pengembangan

Bahasa (P2B) UIN Mataram. Tersedia online pada

https://journal.uinmataram.ac.id/index.php/cordova

understand short conversations. Considerations that were taught in the young learner category, so peer teachers downloaded video conversations with cartoon characters or those who carried out conversations on videos were not human beings but were well-known cartoon characters such as the characters in Big Hero Six cartoons.

c. Short video of a movie or thriller

Short video of a movie or thriller was available in several options contained in Youtube, we just choosed based on our needs.

\section{CONCLUSION}

Based on the research, the students used Youtube as teaching media with different treatments. 1 . Collecting some videos or a video in a PowerPoint the way to serve it to other students, 2. YouTube video was combined with some written explanation in a PowerPoint, 3 . The other students only used a video then played it as a teaching media, 4.students downloaded songs video from Youtube but it was not played in class but the students use the song by changing the lyric. Then the students have it with the variation lyric they already made.

In addition, the peer tacher in playing Youtube videos can be played at the beginning or at the end of the teacher's explanation, with the following explanation:

1. Played at the beginning as warming up learning before the teacher explains the material

2. played after the teacher explains, so students better understand the explanation from the teacher. 
Cordova Jurnal

ISSN (P) 2302-3155,

(e) 2714-5808

Vol. 9, No. 12019
Jurnal kajian Bahasa dan Budaya terbit 2 kali setahun oleh UPT. Pusat Pengembangan

Bahasa (P2B) UIN Mataram. Tersedia online pada

https://journal.uinmataram.ac.id/index.php/cordova

3. YouTUbe is played at the end with a goal as an evaluation tool to measure students' level of understanding of the material being explained.

\section{References}

Brophy, Jere. Vol 10. Using Video In Teacher Education. Advances in Research On Teaching.

Brown, Douglas H. 1987. Principle of Language Learning and Teaching.Englewood Cliffs, New Jersey: Prentice Hall Regents.

Clyde, William. Andrew Delohery. 2005. Using Technology in Teaching, London: Yale University Press

Hemei, J. (1997) Teaching with Video in an English Class, Journal of English Teaching Forum, vol.35-2, pp 45-47

Hymes, Dell. 1988. Foundation in Sociolingusitics: an Etnographic Approach. Philadelphia: University of Pennsylvania Press.

Rivers, W. (1993). CommunicatingNaturally in a Second Language'Cambridge: Cambridge UniversityPress.

Wardhaugh, Ronald. 1998. An Introduction to Sociolinguitics. Oxford: Blackwell Publishers Ltd.

Widdowson, Henry G. 1978. Teaching Language as Commnuication. Oxford: OxfordUniversity Press. 